\title{
Judicial Appointments to the Court of Justice of the European Union
}

\begin{abstract}
The methods to come to judicial appointments can be various and they can be distinguished depending on how different actors interact in the process. Looking at these systems is important as they reveal much about the judicial body itself and the role they perform within a specific legal framework. In this essay the author aims to consider what can be behind the norms contained in the treaties governing the European Union's judicial institutions and to cast some light on what the judicial appointment process can tell about the role performed by the Court of Justice of the European Union in the European context. Such topic has not received massive attention by scholars but yet it assumes great importance considering the vital impact of the rulings of the Court of Justice and the widespread demand for independent and impartial judiciaries. In examining the topic, the author takes into consideration the current rules for judicial appointments set out in the treaties, the newly created panel in charge with the evaluation of the suitability of the appointees to the Court of Justice of the European Union and the need to comply with the requirements set out in the European Convention on Human Rights, in light of the future accession of the European Union to it.
\end{abstract}

Keywords: judicial appointments, Court of Justice of the European Union, independent courts, European Convention on Human Rights

\section{Introduction: judicial selection, an underestimated topic in the European legal studies}

"The appointment of judges to international courts has long been an unstudied area of sovereign activity. It has been described as a 'shrouded process'."1

These words pronounced by Lord Mance ${ }^{2}$ in the occasion of a talk on the composition of the European Court of Justice express the idea that any person, who approaches the topic of international judicial selection, would ultimately get: despite the vital impact of their rulings on the everyday life of thousands of people and on institutions, their composition and the process through which the judges get nominated are often unknown.

Interest to the topic of international judicial selection seems to be a sort of new phenomenon. ${ }^{3}$ Academics has for long time understudied the issue or only incidentally

* LL.M., Ph.D. candidate, Department of Criminal and Comparative Law, University of Florence, Piazza di San Marco, 4 - 50121 Firenze, Italy.

E-mail: camilla.cordelli@unifi.it

${ }^{1}$ Lord Mance, J.: The Composition of the European Court of Justice, talk given to the United Kingdom Association for European Law, 19 ${ }^{\text {th }}$ October 2011, available at www.supremecourt.gov.uk/ docs/speech_111019.pdf

${ }^{2}$ Lord Jonathan Mance is a current member of the Supreme Court of the United Kingdom and also member of the newly created panel in charge with the evaluation of the nominees to the Court of Justice. Further details on such panel will be provided later. Infra, paragraph 3.

3 See e.g. Mackenzie, R.-Sands, Ph.: International Courts and Tribunals and the Independence of the International Judge. Harvard International Law Journal, 44 (2003) 1; Mackenzie, R.-Sands, 
mentioned in relation with wider topics, such as judicial independence. ${ }^{4}$ Indeed, most of the literature on international judicial selection actually consists either in a description of the mechanism for the appointments to some international courts or in a dissertation on judicial independence. As a consequence of the little attention paid to the topic by scholars, the appointment procedures to international courts are often kept undiscovered to the public eye. Transparency and public accountability seem to play a different role and to be subjected to less strict requirements when it comes to judicial appointment to international courts. In fact, the choices made by the States or the international bodies in charge with them are not really discussed nor presented to the general public, which is actually not able, nor even interested most of the time, to form its own opinion on the matter. Nonetheless, there is an unquestionable link between the way a court is composed and the way it operates its duties, and that being acquired, it should be a fundamental rule for international courts to have transparent selection procedures, able to assure the independence and the best quality of the judicial body. Independence and transparency are strongly bound and if the latter is lacking the former can be easily contested.

The Court of Justice of the European Union (CJEU), meaning the comprehensive body composed by the Court of Justice, the General Court and other specialized courts, represents no exception to the described situation. The CJEU has often been considered as the Union's most successful institution, it has had and it still has a primary role in framing European Union law, in developing the European integration and yet, it is the least known institution within the European Union. The decision-making process is opaque and it is fair to concur with Professor Rasmussen who affirmed that few others than some law professors specialized in the study of the Court can actually cite the name of more than one European judge,$^{5}$ probably the one who got appointed by their own home state. An absolute anonymity, which appears even more unreasonable if we consider the broad media coverage dedicated all over Europe to the Justices of the Supreme Court of the United States and their appointments procedure. ${ }^{6}$

On the contrary, when it comes to the European Union, it is not uncommon to get the idea that the topic of judicial selection is being underrated or, at least, considered by scholars merely from a procedural point of view. Each and every book on EU law contains at least a reference to the composition of the CJEU and the appointments procedure. What seems really to be missing is an in-depth analysis of the reasons lying beneath the choice of the particular method and the consequences carried by it, with particular consideration for the context and the political culture in which the appointment procedure takes place. ${ }^{7}$ It

Ph.: Judicial Selection for the International Courts: Towards Common Principles and Practices. In: Kate Malleson-Peter H. Russel (eds): Appointing Judges in an Age of Judicial Power: Critical Perspectives from around the World. Toronto, 2006; Posner, E. A.-Yoo, J. C.: Judicial Independence in International Tribunals. California Law Review, 93 (2005) 1.

${ }^{4}$ See for instance Burbank, S. B.-Friedman, B. (eds): Judicial Independence at the Crossroads. An Interdisciplinary Approach. Thousand Oaks (CA), 2002.

${ }^{5}$ Rasmussen, H.: The European Court of Justice's Competence Transgressions, Poor Reasonings and the Complete Non-transparency of Willensbildung, Legal Opinion, available at forskning.ku.dk/search/publicationdetail/?id=751bab90-1d49-11df-8ed1-000ea68e967b

${ }^{6}$ As again properly pointed out by Professor Rasmussen. Ibid.

7 Judicial independence is a culture, which has to be forged at the national so as the international level. It is strictly related to the political culture of the community and it is shaped by the relations between the branches of government. Therefore, when discussing judicial appointments to the Court 
seems like European scholars promote the idea that knowing why some people have become judges of the CJEU is not as important as knowing how the treaties provide for the judges to be selected. The present work aims to consider what is behind the norms contained in the treaties and to cast some light on what the judicial appointment process can tell about the role assumed by the CJEU in the European context.

\section{From an informal agreement to a codified rule: one judge each Member State}

Three articles of the treaties, as latest amended by the Lisbon Treaty, come into play for the purpose of the present work: Article 19 of the Treaty on the European Union (TEU), Article 253 of the Treaty on the Functioning of the European Union (TFEU), and Article 254 TFEU.

The plain text of these norms represents almost everything that is at the moment known about the composition of the judicial bodies of the Union. Most of the literature focuses on the case law of the CJEU and on its active role in promoting the development of the European Union law and the legal integration of the Member States. The amount of writings and comments on the activity of the CJEU is not balanced with equal interest on the membership of the judicial bodies. As a matter of fact, it is possible to assert that very few words are actually spent on those performing judicial functions at the European Union level and on how they got there.

The first part of Article 19 (2) TEU reads as follows "The Court of Justice shall consist of one judge from each Member State. It shall be assisted by Advocates-General. The General Court shall include at least one judge per Member State”. As set out in Article 253 TFEU, the Judges and the Advocates-General of the Court of Justice shall be persons "whose independence is beyond doubt and who possess the qualifications required for the appointment to the highest judicial offices in their respective countries or who are jurisconsults of recognised competence”. They are appointed for a renewable term of six years, by common accord of the governments of the Member States, "after consultation of the panel provided for in Article 255”. Article 254 TFEU asserts that the Judges of the General Court "shall possess the ability required for appointment to high judicial office".

The rule of one judge per Member State appeared for the first time in the Treaty of Nice and has been confirmed by the drafters of the Treaty of Lisbon. However, long before being fixed in the Treaty, this rule had arisen as a long-lasting practice among the Member States.

It is worthwhile noting that, even though originally such a mechanism was nowhere stipulated, the Member States from the early beginning of the European Communities reached an informal agreement assigning to themselves the power to provide the judges to

of Justice of the European Union it is important not only to point out the mechanism adopted and formalized in the treaties, but also the different interactions between the actors of the process and the cultural reasons that lead to a particular method of selection. That would reveal much on the state of development of judicial independence and would reflect the peculiar political culture of the European Union. Using this approach for the analysis of the specific topic leads to observe the growth of the European Union as a political community. For a recent and complete analysis on the culture of judicial independence see Shetreet, S.-Forsyth, Ch. (eds): The Culture of Judicial Independence. Leiden, 2012. On the concept of political culture see Grossman, J. B.-Sarat, A.: Political Culture and Judicial Research. Washington University Law Quarterly, (1971) 177. 
the Court, picking them from among their citizens. ${ }^{8}$ The origins of this agreement can be traced back to the creation of the first Court of Justice of the European Communities, as a common judicial body of the European Coal and Steel Community (ECSC), the European Economic Community (EEC), and the European Atomic Energy Community (Euratom). Back then the six founding states set out some of the rules that still govern judicial appointment to the Court of Justice of the European Union. In fact, the original treaties contained a formula, framed on the Statute of the International Court of Justice at The Hague, which required the judges to be chosen "from among persons of indisputable independence who fulfill the conditions required for the holding of the highest office in their respective country or who are jurists of recognized competence". ${ }^{9}$ The treaties were silent regarding the nationality of the judges and they only set out that the Member States had to act in "common agreement" when selecting the judges. The practice adopted by the Member States showed that on the one hand they had reached an informal agreement assigning to each of them one position on the Court ${ }^{10}$ and never exerting the veto power on the other states' nominations; on the other hand, they all picked from among their citizens and so it has been done from that moment on, ${ }^{11}$ although it was not back then and still it is not prohibited to nominate a person of a different nationality. ${ }^{12}$

Unlike the nationality rule, which, however, still resists as a praxis, the rule of one judge per Member State is now written in the text of the treaties, even though only with regards to the Court of Justice. ${ }^{13}$ Two main reasons seem to lay beneath the choice of giving

${ }^{8}$ Feld, W.: The Judges of the Court of Justice of the European Communities. Villanova Law Review, (1964), 41.

9 Euratom Treaty, Article 139; EEC Treaty Article, Article 167; ECSC Treaty, Article 32b.

10 They also set special rules for the distribution of the posts depending on who was the President of the Court and who was the President of one of the Communities. At that time the members of the Court of Justice were seven, due to the need to have an uneven composition. It meant that one State could be asked to appoint two judges. Interestingly, it seems that those having two judges were somehow restored for having none of their nationals in such positions. Feld: op. cit. 43-44.

11 Some inferred this rule from the one expressly provided for the executive organs of the Communities, who must be nationals of the Member States. Others asserted that, since it was not expressly required for the Court, that requirement did not apply. Nonetheless, the Member States gave a valid argument to the first theory. Ibid. 41.

12 It is interesting to point out the constrast with the European Court of Human Rights, where there has been the case of Lichtenstein selecting a judge from Switzerland.

13 It is important to note that the different expression used for the General Court ("at least one judge") has allowed the Court of Justice President, Mr. Vassilios Skouris, to request in 2011 the enlargement of the General Court from 27 members to 39. Accordingly to his letter this change to the composition would help the General Court to keep up with the increasing workload. The Parliament has supported this proposition and a legislative procedure had been started, which concluded in August 2012 actually enforcing some major changes to the CJEU Statute (infra fn. 16), but postponing to next year the more political sensitive request such as the one regarding the additional posts to the General Court. In fact the Member States have not been able to reach a shared solution on the way to select the new judges. They showed their own interest in maintaining the balance of one judge per Member State and so doing they actually proved all the flaws of such a system. None would easily agree in giving up on the possibility to nominate an extra judge, thus now it has to be faced the problem of making the General Court efficient with the approval of the Member States. Allegedly the Council of the European Union and the European Parliament's Legal Affair Committee are willing to overcome the Member States resistances and to address this issue by September 2013, which could 
the power of judicial selection to the governments of the Member States. ${ }^{14}$ First, it is important to remember that the European institutions are deemed to suffer a deficit of democratic and political legitimacy. The CJEU is not exempted from this critique. ${ }^{15}$ However, a court composed of members chosen by democratically elected governments might reflect part of the legitimacy recognized to the governments themselves. Moreover, a court made of judges coming from every and each legal system might be seen as more trustworthy by people who will eventually be asked to comply with the rulings rather than a court composed exclusively of foreigners. Confidence in the judiciary is essential to the acceptance of the rulings. This essential value is strengthened by the acknowledgement of the independence, both internal and external of the judicial body. Nonetheless, when it comes to a supra-national court it is fair to imagine that the presence of judges coming from the various national legal system would play a part in creating confidence, trust and consequently legitimacy. The need of representation of the various legal systems which coexist within the European Union is the other side of the coin and it represents the second reason for choosing an appointment system such as the one currently adopted at the CJEU. Knowing that the national background is represented might be very important when it comes to international disputes. Thus, even though no reasonable government would ever consider a judge to the Court of Justice as representing the appointing State itself, her presence means that the domestic context is properly taken into account if necessary for the decision and that it will play a part in the creation of the law of the Union.

Notwithstanding the importance of strengthening legitimacy and giving representation of the different legal systems, one cannot ignore that the current appointment system results to be questionable. It gives an hardly controllable power to the governments, which are not asked to justify their choices or to comply with anything but very broad requirements regarding the qualification of the appointees. It is undoubtable that such a procedure lacks transparency. Moreover, both arguments might reasonably be considered weak, due to the fact that at present time the Court of Justice is quite unlikely to operate in plenary session ${ }^{16}$

require a treaty change. For an overview of the procedure see the dedicated page of the Legislative Observatory of the European Parliament's website, http://www.europarl.europa.eu/oeil/popups/ ficheprocedure.do?reference $=2011 / 0901 \mathrm{~A}(\mathrm{COD}) \& \mathrm{l}=\mathrm{en}$

${ }^{14}$ See e.g. Arnull, A.: The European Union and its Court of Justice. Oxford, 2006. See also Tomuschat, C.: National representation of judges and legitimacy of international jurisdictions: lesson from ICJ to ECJ? In: Pernice, I.-Kokott, J.-Saunders, Ch. (eds): The Future of the European Judicial System in a Comparative Perspective. Baden-Baden, 2006.

15 See e.g. Rasmussen, H.: On Law and Policy in the European Court of Justice. A Comparative Study in Judicial Policymaking. Dordrecht, 1986; Caldeira, G. A.-Gibson, J. L.: The Legitimacy of the Court of Justice in the European Union: models of Institutional Support. The American Political Science Review, 89 (1995) 2, 356-376; Caldeira, G. A.-Gibson, J. L.: Democracy and legitimacy in the European Union: the Court of Justice and its constituents. International Social Science Journal, 49 (1997) 52, 209-224; Gibson, J. L.-Caldeira, G. A.: Changes in the Legitimacy of the European Court of Justice. British Journal of Political Science, 28 (1998) 1, 63-91; Dehousse, R.: The European Court of Justice. The politics of Judicial Integration. NewYork, 1998.

16 According to Article 16 (4) of the Statute of the Court of Justice of the European Union the Court of Justice sits as a full Court when dealing with specific issues: dismissal of the Ombudsman at request of the European Parliament [Article 228 (2) TFEU]; ruling the compulsory retirement or the deprivation of rights to a pension or to benefit of a Member of the Commission for breach of his obligations [Article 245 (2) TFEU and Article 247 TFEU]; ruling the compulsory retirement or the deprivation of rights to a pension or to benefit of Member of the Court of Auditors if he does not any 
and it is not required for a judge coming from a specific Member State to be part of the chamber that will decide a case involving her home country. ${ }^{17}$

Indeed, even though, as already stated, the European way to judgeship has not received considerable attention by scholars, some questions have been raised from time to time and the debate seems to be finally developing. The existence of a strong connection between the independence of the judiciary and the method of selecting judges has never been denied by the academics, but quite surprisingly the topic has been invested with little attention, except for few relevant works which still set the parameters for those who decide to spend some time studying the topic. One of these exceptions is represented by Werner Feld's article published in 1963. ${ }^{18}$ Back then Professor Feld pointed out the odd of the system of national allocation of the posts to the Court of Justice. Some of the questions he posed are still unresolved and its inquiry still leads the work of other scholars in this field, as properly recognised in her 1998 essay by Sally J. Kenney, ${ }^{19}$ which represents itself another exception to the little academic interest.

The European Parliament has also raised the problem of the politicisation of appointments and it has in various occasions proposed alternative selection procedures, which would increase its influence. ${ }^{20}$ For instance, in 1982 it adopted a resolution proposing to be involved in the appointment procedure subjecting the nominations to its ratification. ${ }^{21}$ That would give the European Parliament a power similar to that of the Senate of the United States where the appointment by the President of the Supreme Court Justices is subject to advice and consent by the upper chamber of the Congress. ${ }^{22}$ Furthermore, in 1993 the European Parliament proposed to be invested with the power to elect judges for a nine years non-renewable term. ${ }^{23}$ Such a suggestion, although opposed by the Court of Justice, ${ }^{24}$ was

longer fulfill the requirement or meet the obligations arising form his office [Article 286 (6) TFEU]. The Court might also decide, under Article 16 (5), to sit as a full court in cases of exceptional importance, after hearing the Advocate General.

It is interesting to mention that since the Court of Justice rarely operates as a full court and in order to have more judges partecipating in the decisions, on August 11, 2012 the European Parliament and the Council have adopted a Regulation (No 741/2012) which amends Article 16 (2) increasing the number of judges sitting in the Grand Chamber from 13 to 15.

17 As, on the contrary, it is the case for the European Court of Human Rights.

18 Feld: op. cit.

19 Kenney, S. J.: The Members of the Court of Justice of the European Communities. Columbia Journal of European Law, (1998) 5, 101. See also Kenney, S. J.: The Judges of the Court of Justice of the European Communities. In: Kenney, S. J.-Reisinger, W. M.-Reitz, J. (eds): Constitutional Dialogues in Comparative Perspective. New York, 1999.

${ }^{20}$ For an overview on the proposal presented by the Parliament to increase its influence on the procedure see Kenney: The Judges of the Court of Justice of the European Communities. op. cit.

${ }^{21}$ Resolution of the European Parliament's Position Concerning the Reform of the Treaties and the Achievement of European Union, 1982, OJ (C 238) 25, 6 July 1982.

22 Neville Brown, L.-Kennedy, T.: The Court of Justice of the European Communities. London, 2000. 48.

${ }^{23}$ Debates of the European Parliament, 9 February 1994, n. 3-442/139, Role of the European Parliament in the Appointment of Judges to the Court of Justice of the European Communities. See on the proposition of the Parliament, Chalmers, D.-Tomkins, A.: European Union Public Law. Cambridge, 2007. 144-145.

${ }^{24}$ In 1994, the European Council decided to set up a Study Group to prepare for the work of the 1996 Intergovernmental Conference provided for under Article N(2) of the Treaty on European Union. 
eventually included in the Resolution on the General Outline for a Draft Revision of the Treaties ${ }^{25}$ but yet not adopted by the Member States.

More recently, during the preparatory works for the Constitution for Europe, the Discussion Circle on the Court of Justice considered the question of reforming the appointment procedures both for the Court of Justice and the Court of First Instance (now General Court) ${ }^{26}$ Although the majority of the members of the Circle concluded that all the provisions regarding the number of the judges to both courts, the appointment procedure, and the length of term, should remain unchanged, it is interesting to note what other solutions had been considered. In fact, "some members felt that appointment should be by act of the Council and, of these, several felt that the Council should act by a qualified majority". ${ }^{27}$ Also, the Circle under the suggestion made both by the President of the Court of Justice and the President of the Court of First Instance, considered the possibility to introduce a twelve or nine years non-renewable term of office. Finally, it expressed its favor to the creation of a panel of experts for the evaluation of the nominees (as the one that will be then provided for under Article 255 TFEU), which would include one person nominated by the Parliament, even though that raised the contrary opinion of one member of the Circle.

Yet, it is interesting to recall the Report of the Court of Justice of the European Communities published in 1995 by the Court of Justice itself. In this report, prepared on the occasion of the 1996 Intergovernmental Conference, ${ }^{28}$ it was clearly affirmed that the Court acknowledged the above-mentioned reasons underneath the choice for a certain process of judicial selection. Nevertheless, considering the already large composition of the European Court of Justice, increasing the membership would have made concrete the risk of crossing "the invisible boundary between a collegiate court and a deliberative assembly", ${ }^{29}$ especially when the Court was sitting as a full court. ${ }^{30}$ This concern was particularly strong considering the prospects of enlargement of the Union, which would have considerably increased the members of Union, and consequently the judges to the Court. Therefore, the Court suggested in the report not to maintain the link between the number of the judges and the number of the Member States, "even though the treaties do not provide for any link between

It asked the institutions to draw up reports on the operation of the Treaty and the Court responded filing its own report. On the specific topic we are dealing with, the Court expressed its firm opposition. As written in paragraph 17, the proposal of the Parliament was considered unaccetable. The Court stated in the report that "Prospective appointees would be unable adequately to answer the questions put to them without betraying the discretion incumbent upon persons whose independence must, in the words of the treaties, be beyond doubt and without prejudging positions they might have to adopt with regard to contentious issues which they would have to decide in the exercise of their judicial function." Report of the Court of Justice on certain aspects of the application of the treaty on European Union, Luxembourg, May 1995, available at http://www.cvce.eu/content/publication/2003/4/2/ 3644862f-2e8f-4170-9616-e573a41b61c5/publishable_en.pdf

${ }^{25}$ Resolution on the General Outline for a Draft Revision of the Treaties, 1997, OJ (C 33) 66. (B4-0040/97), 16 January 1997.

${ }^{26}$ Final Report of the Discussion Circle on the Court of Justice, March 25, 2003, available at http://european-convention.eu.int/pdf/reg/en/03/cv00/cv00636.en03.pdf

27 Ibid.

${ }^{28}$ Final Report of the Discussion Circle on the Court of Justice, supra fn. 26.

29 Ibid.

30 Supra fn. 16. 
nationality and membership of the Court”. ${ }^{31}$ As it is well known by now, that rule of one judge per Member State became a written one few years later.

Indeed, none of the different proposals coming from the scholars, the European Parliament, and the Court itself, have been embraced by the Member States, which, while drafting the Constitution for Europe, later transformed into the Lisbon Treaty, decided to maintain the status quo.

\section{The new panel}

One important innovation is actually contained in the Lisbon Treaty. Under Article 255 TFEU, it is created a panel in charge with the evaluation of the suitability of the appointees has been created. This is probably the only response to those who hoped for some innovation with regards to the appointment procedure. At first glance, this body seems to have the possibility to partially reframe the judicial appointments in Europe, even though the final say on the procedure rests in the hands of the Member States. According to the treaties and the Rules regulating the panel, its role is quite limited, as it can only provide a not binding opinion on the nominees proposed by the national governments. Nonetheless, in the short time the panel has operated, it has demonstrated to be willing to perform a more incisive role than the one originally assigned to it. Indeed, the opinions on the suitability of the nominees, even though still merely advisory, are taken into great consideration by the Member States.

Trying to evaluate the panel is far from easy, as very little is known about it and information are difficult to find. Therefore, for the purpose of the present work we particularly rely on the insights offered by Lord Mance, ${ }^{32}$ in order to evaluate the practical impact of the innovation brought by Article 255 TFEU.

In the early months of 2010, the President of the Court of Justice, Mr. Skouris, submitted two important recommendations, one setting the rules for the panel and the other nominating the seven members of the brand new body. ${ }^{33}$ Two decisions of the Council of the European Union followed the recommendations. ${ }^{34}$ Introducing the rules for the panel, the President explained his will to limit the provisions only to issues relating to "the powers of the panel and the relations which the panel may have with other parties." ${ }^{35}$ Therefore, the shortness of the rule is actually to be attributed to a specific intention of the drafters, who decided for what concerns other issues to defer to the provisions of the TFEU or to the practice of the panel itself. The TFEU does not actually contain provisions other than Article 255 regarding the panel. That means that at the end of the day, this body is self-

31 Final Report of the Discussion Circle on the Court of Justice, supra fn. 26.

32 Lord Mance: The Composition of the European Court of Justice. op. cit.

${ }^{33}$ Recommendation relating the operating rules of the panel provided for in Article 255 TFEU of 11 January 2010 (5195/10) and Recommendation concerning the composition of the panel provided for in Article 255 TFEU of 2 February 2010 (5932/10).

34 Council Decision relating to the operating rules of the panel provided for in Article 255 of the Treaty on the Functioning of the European Union, 2010, OJ (L 50) 18 (2010/125/EU), 25 February 2010; Council Decision appointing the members of the panel provided for in Article 255 of the Treaty on the Functioning of the European Union, 2010, OJ (L 50) 20, 25 February 2010.

35 Recommendation relating the operating rules of the panel provided for in Article 255 TFEU, supra fn. 33. 
governed and can autonomously develop its own practice. Such a thing has indeed happened, as clearly stated in Lord Mance's lecture.

The original rules are only nine and they are limited to provide general principles that should guide the advisory body. Interestingly, Rule No. 2 refers to the composition of the panel, stating that the seven members, including the one nominated by the European Parliament, shall be chosen among judges of the national supreme courts and lawyers. According to Rule No. 3 the members of the panel are appointed for four years and their mandate can be renewed. ${ }^{36}$

When in 2010 President Skouris proposed the names of the seven members of the panel, he made clear the will to accomplish a twofold goal. On the one hand, there was the necessity to assure even representation of the European legal systems; on the other hand, the membership of the panel had to be geographically balanced. It is noteworthy that the President does not refer to the necessity of having a gender balanced composition. Unfortunately, nothing is said in the recommendation that can help understanding the reasons behind these choices. Nonetheless, the list of names suggests a series of considerations.

Firstly, it is interesting to observe that with the only exception of Ms Vallelersundi, the member nominated by the Parliament, all the other members come from the bench. It would not be correct to assert that the members have a common professional background, since two of them are former judges of the European judicial bodies and the other exert their functions in different national courts. Nonetheless, it is relevant that six members on seven are judges. Moreover, observing the composition of the panel from another perspective it seems even more relevant that the one component of the panel nominated by the Parliament is a person with political experience, having Ms Vallelersundi had a seat at the European Parliament. This data it is particularly interesting in light of the process that brought to the drafting of Article 255. As previously pointed out, the role of the European Parliament in the appointment process has been strongly debated during the drafting of the Constitution for Europe and the subsequent period of time that brought to the adoption of the Lisbon Treaty. Once excluded the power of the Parliament to appoint a judge, the Discussion Circle on the Court of Justice concluded that the attribution to the Parliament of the power to nominate one member of the panel was appropriate, despite the contrary opinion of one participant to the Discussion Circle, who was concerned with the risk of politicisation of the process. In fact the first person the Parliament selected for the panel stands out from the rest of the membership for her background. Ms Vallelersundi is a lawyer, but more importantly, she was a member of the European Parliament. Unlike the other members of the panel, Ms Vallelersundi's nomination has an undoubtable political dimension. Nonetheless, the influence of the Parliament over the appointment procedure is limited and it is hard to recognize a real risk of politicisation. The Parliament has the power to select only one person on seven, therefore the power of this member may be easily neutralized by the other members. Moreover, it is to remember the extremely limited power should be

36 Currently, the seven members of the Panel are: Mr Jean-Marc Sauvé, President of the Panel, currently Vice President of the Council of State of the French Republic; Mr Peter Jann, judge at the ECJ from 19 January 1995 to 6 October 2009; Lord Mance, currently member of the Supreme Court of the United Kingdom; Mr. Torben Melchior, currently President of the Supreme Court of Denmark; Mr. Péter Paczolay, currently President of the Constitutional Court of Hungary; Ms Ana Palacio Vallelersundi, lawyer in Madrid and member of the European Parliament between 1994 and 2002; Ms Virpi Tiili, judge at the CFI from 18 January 1995 to 6 October 2009. 
remembered, even though, as recalled by Lord Mance, this body has from the very beginning tried to be as effective as possible. As a matter of fact, the persuasive force of the opinions of the panel is not enough to overcome some objective limits, such as the impossibility for the experts to take into account specific needs of the European judicial bodies, as they can only evaluate the candidates picked by the Member States. The panel cannot evaluate careers and expertises or balance skills, experience or gender on the Court and the Member States entirely maintain their prerogatives in picking one name from the bunch. Thus, considering the limited effect of the parliamentary nomination over the work of the panel, and the limited effect of the panel over the appointment process, it seems quite unlikely that the presence of a member nominated by the European Parliament may resemble a threat to the independence of the body. This kind of critique may be attributed to the European tradition (at least in continental Europe) of isolating the judicial power from the other branches of the government. A direct parliamentary participation in the selection of the judiciary it is quite rare in Europe and this has deep historical roots. On the contrary, the selection of the justices that will sit at the Supreme Court bench in the United States is a duty of the Executive branch of the Government. In addition to that, the role of advisory body, which ultimately gives its consent to the appointment, is performed by the Senate of the United States. ${ }^{37}$

Few more things need to be pointed out with regard to the panel provided for in Article 255, and once again the comparison with American experience might be very helpful. According to Rule No. 6, once the government of the Member State has found the name of the candidate, the General Secretariat of the Council is required to transmit it to the President of the panel. Then, if the body finds it necessary, it can ask the national government to provide further information. As set out in Rule No. 7, the panel has also the power to call the candidate for a hearing that may be held in private. At a first glance, it looks like the panel has actual discretion whether to meet the potential judge or not. Actually, the discretion may be the result of a compromise reached among different views on how the panel should operate. In fact, the Discussion Circle had excluded the possibility for the panel to hold hearings. The panel has interpreted the Rule "to mean that in case of a new appointment it must have a hearing, in the case of a re-appointment it cannot have a hearing" ${ }^{38}$ It is interesting to observe that the hearings are excluded in the cases of re-

37 Even though Article 2(2) of the Constitution of the United States refers to the body as a whole, since 1868 the Senate has deferred part of the "advice and consent" function to a standing committee: the Judiciary Committee. The Senate Judiciary Committee is one of the most influential standing committee in the United States Senate. It performs legislative and oversight roles, not limited to the one concerning judicial nominations to the federal bench. However, massive attention to its activity is brought by the screening conducted on the nominees to the Supreme Court of the United States. The membership of the Committee is determined at the start of every Congress according to a ratio of majority to minority members in the Senate. Each party decides the members that will seat in the Committee and consequently two resolutions are adopted by the Senate: one regarding the majority membership; and one regarding the minority membership. The Committee itself will then divide the members into Subcommittee panels, although the hearings of the judicial candidates happen in front of the full Committee. The total number of senators composing the Committee is now 18: 10 for the majority and 8 for the minority. All the members of the Committee are politicians selected within their own party, however it is of some interest to note that most of them have a specific background as attorneys.

38 Lord Mance: The Composition of the European Court of Justice. op. cit. 
appointment. Apparently the panel has considered the a posteriori evaluation of the judge as something that would threat his or her independence, however, one could argue that it is actually after a first term of office that the panel would have concrete elements to give an opinion on the suitability of the person. That being said, it is remarkable that, in any event, the hearings would not be public. According to Rule No. 8, the panel is compelled to state the reasons for its opinions and to forward them to the representatives of the Governments of the Member States. Moreover, if the Presidency requires it, the President of the panel shall present that opinion to the representatives of the Governments of the Member States' meeting within the Council. No other duty of publicity is placed over the panel's work.

At least five members of the panel must participate at any meeting and, as stated under Rule No. 5, the deliberations of the Panel are to be taken in camera. This means that, unless the body will develop a different practice in the next years and it will increase transparency, from the outside it is possible to have only an ex post knowledge of the work of the panel. However, due to the increasing influence of the decisions taken at the European level by the Court of Justice and the General Court, it might be reasonable to ask for public hearings similar to the ones that usually take place in front of the Senate of the United States. That would balance the lack of transparency of national governments' decisions about the nominees.

As more than once observed, the Member States are substantially free to decide who to appoint to the CJEU. Many different reasons may lay beneath the choice and actually none of them is clearly expressed. The introduction of an advisory panel seems to respond to the necessity to assure that the person selected by the national government, to whom the other governments had expressed their consent, will fit in the CJEU. In fact Article 255 specifically refers to the panel as a body called to express an opinion on the suitability of the candidates. Unlike the Senate in the United States, the panel does not have the power to give the consent to the nomination; its function appears to be narrowed to give an opinion with respect to a decision still under the control of the national governments. Nonetheless, requiring public hearings would have been important to increase the transparency of the whole process. The Member States would have their autonomy in the decision untouched, but the candidates would have been placed under public observation prior to their formal admission to the European judiciary.

Still, it is to mention that the publicity given to the confirmation hearings in the United States in occasion of the modern appointments is not subject to unanimous approval. Some scholars argue that publicity opens to excessive attention by the media and this makes the process even more controversial. However, for what it concerns the Court of Justice, but also the General Court, a little bit more of knowledge would be desirable and would compensate the current obscurity. Finally, another argument may be brought to oppose public hearings. In terms of time and economic resources, setting hearings open to public would probably cost more than private hearings. Especially, because the rules for the panel seem to leave the decision whether to hold the hearings under the discretion of the body. This argument may have some merits, however, the interest for transparent appointments should have precedence. 


\section{The requirements set by the ECHR and the European Charter for an independent judiciary}

Finally, the topic of judicial appointments to the CJEU acquires new relevance in light of Article 6 (2) TEU, ${ }^{39}$ which envisages the accession of the Union to the European Convention on Human Rights (ECHR). The Convention, which already represents a source of inspiration for the Court, will inevitably affect the practice adopted by the Union with regard to judicial appointments, as Article 6 (1) of the Convention affirms the right to a hearing "by an independent and impartial tribunal" ${ }^{40} \mathrm{~A}$ similar provision is also contained in Article 47 (2) of the Charter of Fundamental Rights of the European Union, ${ }^{41}$ which has acquired a new legal status after the entering into force of the Lisbon Treaty. In order to comply with these rules, especially the one contained in the Convention as interpreted by the European Court of Human Rights, the European Union needs to make sure that the judicial appointment procedure leaves no room for doubts on politicization or lack of independence.

The European Court of Human Rights (ECtHR) has provided from early times an interpretation of the word "independent" as referred to judgeship. Whenever the ECtHR deals with issues regarding the right to an independent and impartial tribunal it states, as a general principle, that "in order to establish whether a body can be considered "independent", regard must be had, inter alia, to the manner of appointment of its members and to their term of office, to the existence of guarantees against outside pressures and to the question whether the body presents an appearance of independence." ${ }^{\prime 2}$ The connection between the appointment procedure and the perceived and concrete independence of the judges emerges clearly. As a consequence, the European Union is now more than ever compelled to consider what has been stated by the ECtHR. The appointment procedure, as set out under the Treaty of Lisbon, is not flawless and probably not completely in line with the ECHR and the case law of the Strasbourg Court.

Both Article 253 and Article 254 TFEU require the Member States to appoint judges "whose independence is beyond doubt" and the Statute of the CJEU provides in Title 1 for

39 Article 6 (2) TEU: The Union shall accede to the European Convention for the Protection of Human Rights and Fundamental Freedoms. Such accession shall not affect the Union's competences as defined in the treaties.

40 Article 6 (1) ECHR: In the determination of his civil rights and obligations or of any criminal charge against him, everyone is entitled to a fair and public hearing within a reasonable time by an independent and impartial tribunal established by law. Judgement shall be pronounced publicly by the press and public may be excluded from all or part of the trial in the interest of morals, public order or national security in a democratic society, where the interests of juveniles or the protection of the private life of the parties so require, or the extent strictly necessary in the opinion of the court in special circumstances where publicity would prejudice the interests of justice.

${ }^{41}$ Article 47 (2) Charter: Everyone is entitled to a fair and public hearing within a reasonable time by an independent and impartial tribunal previously established by law. Everyone shall have the possibility of being advised, defended and represented.

42 See among the others Sacilor Lormines v. France, no. 65411/01, judgment of 9 November 2006, Reports of Judgments and Decisions 2006-XIII; Brudnicka and Others v. Poland, no. 54723/00, $\S$ 38, ECHR 2005-II; Findlay v. the United Kingdom, judgment of 25 February 1997, Reports of Judgments and Decisions 1997-I, p. 281, § 73; Bryan v. the United Kingdom, no. 19178/91, judgment of 22 November 1995, Series A no. 335-A; Langborger v. Sweden, judgment of 22 June 1989, Series A no. 155, p. 16. para 32. 
specific guarantees. ${ }^{43}$ However, independence is certainly threatened because of the broad power attributed to the national governments when picking the nominees. The lack of transparency in the selection procedures adopted by the Member States and the short renewable term, make the current system biased. The anonymity when adopting the decisions, the absence of any sort of dissenting opinion and the distribution of the cases to chambers (which means that not necessarily the judge appointed by one State would decide the case involving his own country) only partially balance the threat to independence.

Judicial independence is considered a sensitive topic not only by the ECtHR but also by the Council of Europe, which has dedicated wide attention to it. ${ }^{44}$ For this purpose, it has from time to time required ${ }^{45}$ the High Contracting Parties of the Convention to increase transparency, accountability, and consistency in the national procedure for nominating candidates to the ECtHR to be elected by the Parliamentary Assembly. In addition to the effort of the Council itself, the International Centre for the Legal Protection of Human Rights (Interights) published in 2003 a report entitled "Judicial Independence: Law and Practice of Appointments to the European Court of Human Rights”. ${ }^{46}$ From the detailed analysis developed by Professor Dr. Jutta Limbach and the other components of the group, it emerges that the national procedures "are often inadequate, politicised and so opaque that they are barely understood, even by some judges appointed by them. There is no meaningful review of these procedures at the international level, and no effective safeguards against

43 Article 2 Statute of the CJEU: Before taking up his duties each Judge shall, before the Court of Justice sitting in open court, take an oath to perform his duties impartially and conscientiously and to preserve the secrecy of the deliberations of the Court.

Article 3 (1): The Judges shall be immune from legal proceedings. After they have ceased to hold office, they shall continue to enjoy immunity in respect of acts performed by them in their official capacity, including words spoken or written.

Article 4 (1), (2), (3): The Judges may not hold any political or administrative office.

They may not engage in any occupation, whether gainful or not, unless exemption is exceptionally granted by the Council, acting by a simple majority.

When taking up their duties, they shall give a solemn undertaking that, both during and after their term of office, they will respect the obligations arising there from, in particular the duty to behave with integrity and discretion as regards the acceptance, after they have ceased to hold office, of certain appointments or benefits.

${ }_{44}$ An important contribution to the debate on judicial appointments has come from the Venice Commission, which has studied the topic both at the national and international or supra-national level. With reference to the former, it is interesting to mention the analysis on the appointments procedures to constitutional courts The Composition of Constitutional Courts, CDL-AD(2007)028. The Venice Commission particularly focuses on proposing a list of standards which should be respected in order to ensure internal ad external judicial independence. For an overview see the Venice Commission's Report on the Judicial System. Part I: The Independence of Judges, CDL-AD(2010)004.

45 As a mere example see the Guidelines of the Committee of Ministers on the selection of candidates for the post of judge at the European Court of Human Rights, Adopted by the Committee of Ministers on 28 March 2012 at the 1138th meeting of the Ministers' Deputies, CM(2012)40 final, available at https://wcd.coe.int/ViewDoc.jsp?Ref=CM(2012)40\&Language=lanEnglish\&Ver=final\&S ite $=$ COE \&BackColorInternet $=$ C3C3C3\&BackColorIntranet $=$ EDB021\&BackColorLogged $=$ F5D383

${ }^{46}$ Limbach, J.-Cruz Villalón, P.-Errera, R.-Lester, A.-Morshchakova, T.-Sedley, S.-Zoll, A.: Judicial Independence: Law and Practice of Appointments to the European Court of Human Rights. London, May 2003. 
arbitrariness." ${ }^{\text {47 }}$ The report concludes stating that "while accepting the diversity of legal systems in Europe, minimum standards should be issued to States on the essential procedural steps and safeguards that should be undertaken in the judicial nomination process". ${ }^{48}$

A similar conclusion could also apply to the Court of Justice of the European Union and it appears quite likely that some of these inputs to the European Union will come from the ECtHR itself, which has posed under strict scrutiny the national procedures, taking into account the criticism contained in the report and issuing a series of recommendations. The European Union will be then expected to comply with these requirements not only as a member of the Convention, which will eventually candidate a judge to the ECtHR, but also in regard with its own Court because of the legal obligation under Article 6 of the Convention.

\section{Rethinking judicial appointments to the Court of Justice of the European Union}

Concluding the present essay, it is important to reflect on possible reforms to the appointment procedure, which should take into account the concerns expressed by the Strasbourg Court and other observers mentioned so far. In developing the topic, it is important to consider not only what kind of body the Court of Justice has become, but also what kind of body the Union would aim it to be. Given the important role played in the process of European integration, the Court of Justice should be preserved from critiques regarding its independence, which could damage its reputation and diminish its already questioned legitimacy. Therefore, in the last part of the present work I try to evaluate a possible and maybe desirable reform scenario for judicial appointments.

It has been pointed out that most of the work of the European judges is done in chambers. Justifying the current system of appointments with the need to provide a national legal background does not sound reasonable anymore. The Court of Justice of the European Union should be a totally independent institution and breaking the link between judges and States should be the first step to the take in the direction of developing a real Court of the European Union, living of autonomous legitimacy. In this sense it is interesting to spend some words on the proposal presented in 2011 by the President of the Court of Justice to increase the number of judges of the General Court from 27 to $39 .{ }^{49}$ The resistance immediately shown by the Member States and the impossibility to reach a compromise on a new appointment system for the General Court, led the European Parliament to postpone such a controversial reform and it all confirms how fearful are the appointing states to have their selection powers diminished.

The Commission, in an opinion released on September 30, 2011, has proposed to the Member States two possible models for filling the vacant seats at the General Court. ${ }^{50}$ Even being the issue reserved for later analysis, the European Union's institutions and the States will have to take a step towards a reform of the appointment procedure to the General Court, therefore the two suggestions written in the Commission opinion are worth to be

47 Ibid.

48 Ibid.

49 Supra fn. 13.

50 Commission opinion on the requests for the amendment of the Statute of the Court of Justice of the European Union, presented by the Court, September 30th, 2011, available at http://eur-lex. europa.eu/LexUriServ/LexUriServ.do?uri=COM:2011:0596:FIN:EN:HTML 
taken into consideration. The first model would be based on a rotating system, to be regulated according to a previously drawn up list. The General Court would be composed of at least one judge per Member States, as the treaties already command, but some States would have (maximum) two judges sitting on the bench. According to the Commission opinion, their terms must be staggered over the three year period of partial renewal, in order to avoid competition among the judges, which might happen if their terms happen to fall at the same time. The second model proposed by the Commission takes more into account the specificity of the General Court and tries to balance it with the need for even national representation. The General Court is, according to the Commission opinion "structured more in terms of specialised chambers for each subject". ${ }^{1}$ That being said the Commission proposed to nominate half of the new judges accordingly to this need of specialised skills. Either way, it is self-evident that the States need to find a way to break, at least for the General Court, the bound they have created between number of judges and number of States.

Again, in rethinking judicial appointments to the Court of Justice of the European Union it would be important to give the panel provided for under Article 255 TFEU more influential role, allowing it to issue a binding opinion on the suitability of the nominees and also requiring the publicity of the hearings. At the same time, it would be essential that the States reveal the procedure adopted for the selection and the reasons behind the choice following, for instance, the example set by the Netherlands. ${ }^{52}$ The panel should be able to determine whether the candidate not only possesses the legal qualification to perform the role, but also if he or she would fit the Court needs in term of diversity. Giving this power to an independent body of expert instead of to the Parliament or the Council would preserve form undue political influences. Moreover, giving the power of screening the nominees to politicians coming from the same States as those which have the power to nominate is unlikely to alter the predominance of the States.

Finally, a change, that could be applicable even leaving untouched the current appointment procedure, would be to introduce a longer non-renewable term. In fact, this kind of reform should be on top of the reform's list of the Union and it could coexist with all the other proposals mentioned above. Introducing a longer term of office would partially balance the flaws of the current system and would at least reduce the risk of having undue influences on the judges from the governments.

As above mentioned, reforming the mechanism for judicial appointments is a politically controversial issue and that is proved by the postponement of the project of increasing the number of judges of the General Court. In a time of crisis, such as the current one, when the European Union is facing hard battles every day and when national governments seem sometimes to be willing to take back part of their prerogatives, it is easily understandable how difficult it becomes asking to endorse this reform project. Nonetheless, it would be of great importance to finally rethink the appointment system to at least the General Court. Adopting one of the two models proposed by the Commission would show the will of the Member States to finally trust the judicial institution and its

51 Ibid.

52 As a consequence of the introduction of the scrutiny to be performed by the panel, the Dutch government has introduced a merit-based competition to select its nominees to the Court of Justice. It seems like many States are actually following this example. On the contrary, others such as Italy still resist in not disclosing their own selection procedures. 
ability to create a synthesis of the different European legal tradition and to create the European Union's law, even without the contribution of an equal number of judges per Member States. Moreover, adopting the second system proposed by the Commission would mean to put at the center of the discussion the specific qualification of the appointees, instead of his or her nationality and that would be a small step but yet a strong signal towards a less political system of judicial selection. The European Union should put such a reform in its future agenda and, at the same time, the Member States should enforce new rules for the selection of their nominees, which would ensure transparency of the procedures. It would not diminish the sovereignty of the States but it would at least increase the perceived legitimacy of the Court. 